\title{
An Oligonucleotide Microarray Resource for Transcriptional Profiling of Bradyrhizobium japonicum
}

\author{
Woo-Suk Chang, ${ }^{1,2}$ William L. Franck, ${ }^{1,2}$ Eddie Cytryn, ${ }^{3}$ Sooyoung Jeong, ${ }^{4}$ Trupti Joshi, ${ }^{1,5,6}$ \\ David W. Emerich, ${ }^{4}$ Michael J. Sadowsky, ${ }^{3,7}$ Dong Xu, ${ }^{1,5,6}$ and Gary Stacey, ${ }^{1,2,4,5,8}$

\begin{abstract}
${ }^{1}$ National Center for Soybean Biotechnology and ${ }^{2}$ Division of Plant Sciences, University of Missouri, Columbia 65211, U.S.A.; ${ }^{3}$ Department of Soil, Water, and Climate, University of Minnesota, St. Paul 55108, U.S.A.; ${ }^{4}$ Division of Biochemistry, ${ }^{5}$ Christopher S. Bond Life Sciences Center, and ${ }^{6}$ Department of Computer Science, University of Missouri; ${ }^{7}$ BioTechnology Institute, University of Minnesota; ${ }^{8}$ Department of Molecular Microbiology and Immunology, University of Missouri
\end{abstract}

Submitted 3 May 2007. Accepted 18 June 2007.

\begin{abstract}
A DNA microarray, comprising 70-mer oligonucleotides, representing 8,453 open reading frames (ORFs), was constructed based on the Bradyrhizobium japonicum strain USDA110 genomic sequence. New annotation predicted 199 additional genes, which were added to the microarray and were shown to be transcribed. These arrays were used to profile transcription in cells under a variety of conditions, including growth in minimal versus rich medium, osmotic stress, and free-living cells versus bacteroids. Increased expression was seen for genes involved in translation, motility, and cell envelope synthesis in rich medium whereas expression increased in minimal medium for genes involved in vitamin biosynthesis and stress responses. Treatment with 50 $\mathrm{mM} \mathrm{NaCl}$ activated stress-inducible genes but repressed genes involved in chemotaxis and motility. Strikingly, no known transport systems for accumulation of compatible solutes or osmoprotectants were induced in response to osmotic stress. A number of nif, fix, and hup genes, but not all, were upregulated in bacteroids. The $B$. japonicum type III secretion system, known to be important in early nodulation, was downregulated in bacteroids. The availability of a reliable, low-cost $B$. japonicum microarray provides a useful tool for functional genomic studies of one of the most agriculturally important bacteria.
\end{abstract}

Additional keywords: transcriptomics.

Transcriptional profiling allows for a comprehensive view of changes in gene expression that occur as a result of a cellular response to environmental perturbations. Rhizobia are of interest due to their ability to symbiotically fix nitrogen with leguminous plants. The culmination of this symbiotic relationship is the formation of root nodules, in which the bacteria convert atmospheric dinitrogen into ammonia to be used by the host plant in exchange for host-derived carbohydrates and nutrients. Nodule initiation and development is a complex process involving signal exchange between both symbiotic partners and differentiation of the rhizobia into bacteroids inside nodules. Soybean is one of the major crops produced worldwide and, therefore, knowledge of the Bradyrhizobium

Corresponding author: W.-S. Chang; Telephone: (573) 884-4799; Fax: (573) 884-9676; E-mail: changwo@ missouri.edu

* The $e$-Xtra logo stands for "electronic extra" and indicates that additional material is available online. A supplemental figure and four supplemental tables are published online. japonicum-soybean symbiosis has great agricultural and ecological benefits.

Transcriptomics in rhizobia has been enabled by the availability of the complete genome sequences for Mesorhizobium loti (Kaneko et al. 2000), Rhizobium etli (Gonzalez et al. 2006), Sinorhizobium meliloti (Galibert et al. 2001), R. leguminosarum (Young et al. 2006), and B. japonicum (Kaneko et al. 2002). Indeed, Affymetrix GeneChips and polymerase chain reaction (PCR) fragment- and oligonucleotide-based microarrays are available for $S$. meliloti (Ampe et al. 2003; BarloyHubler et al. 2004; Barnett et al. 2004; Becker et al. 2004; Berges et al. 2003; Davalos et al. 2004; Puskas et al. 2004; Ruberg et al. 2003) and M. loti (Uchiumi et al. 2004). Recently, an Affymetrix oligonucleotide array was developed for B. japonicum (Hauser et al. 2006; Rudolph et al. 2006; Yang et al. 2006). Relatively few studies have been done with $B$. japonicum microarrays, perhaps due to the high cost of the Affymetrix platform. However, gene expression in $S$. meliloti has been well-studied under a variety of conditions, including growth in minimal versus rich medium (Barnett et al. 2004; Becker et al. 2004), osmotic (Ruberg et al. 2003) and oxidative stress (Barloy-Hubler et al. 2004) under microoxic versus oxic conditions (Becker et al. 2004; Hauser et al. 2006; Uchiumi et al. 2004), as free-living cells versus bacteroids (Ampe et al. 2003; Barnett et al. 2004; Becker et al. 2004; Uchiumi et al. 2004), and under conditions influencing nitrogen regulation (Davalos et al. 2004; Puskas et al. 2004).

A key aspect of bacterial survival in soil is successful adaptation to environmental fluctuations, such as changes in temperature, water availability, $\mathrm{pH}$, nutrients, and salinity. Rhizobia in fallow soil must persist until they encounter the nutrient-rich rhizosphere and initiate infection of their compatible host. In order to enhance symbiotic nitrogen-fixation, legume seeds often are inoculated with rhizobial cultures prior to sewing. A preferred method for delivery is seed coating; however, this approach often is unsuccessful for B. japonicum because they do not survive the drying process. Roughley and associates (1993) reported that $95 \%$ of Bradyrhizobium spp. died within $4 \mathrm{~h}$ of inoculation of the seed and planting in which the bacteria were likely exposed to desiccation-mediated osmotic stress. Therefore, the ability of B. japonicum to survive osmotic stress could have practical importance. A number of studies have shown that B. japonicum fails to grow at concentrations exceeding $100 \mathrm{mM} \mathrm{NaCl}$ (Boncompagni et al. 1999) whereas some rhizobia, including $S$. meliloti and $M$. loti, are tolerant to 300 to $700 \mathrm{mM} \mathrm{NaCl}$ (Boncompagni et al. 1999; Elsheikh 1998; Elsheikh and Wood 1990; Zahran 1999). Once free-living 
bacteria develop into bacteroids within the nodule, they also become more osmotically sensitive. Moreover, within the nodule, a transition occurs from an oxygen-rich to an oxygen-poor environment. Indeed, oxygen availability has been shown to be a major regulator of gene expression in bacteriods (Ampe et al. 2003; Barnett and Fisher 2006; Becker et al. 2004; Fischer 1994; Hauser et al. 2006; Layzell et al. 1990).

In order to improve inoculant performance and to optimize the benefits of biological nitrogen fixation, it is important to fully understand how $B$. japonicum responds to alterations in its environment and to the physiological changes that occur during bacteroid differentiation. To aid in this understanding, we constructed a low-cost, oligonucleotide-based DNA microarray for B. japonicum. These arrays, which contain 8,453 predicted open reading frames (ORFs) from $B$. japonicum and 36 control genes, were used to profile $B$. japonicum gene expression in cells grown in rich versus minimal medium, cells treated with $50 \mathrm{mM} \mathrm{NaCl}$, and free-living cells versus bacteroids. Results of these studies show that the constructed arrays are useful for transcriptional profiling of B. japonicum grown under a variety of conditions.

\section{RESULTS AND DISCUSSION}

\section{Genome annotation.}

The $B$. japonicum strain USDA110 genome was sequenced and machine-annotated by the Kazusa DNA Research Institute (KDRI) (Kaneko et al. 2002). Although 8,317 ORFs were identified by this group, an examination of this initial annotation suggested that some ORFs were missed. Our analysis suggested the presence of an additional 199 ORFs (Supplemental Table 1) that were overlooked in the original annotation (Kaneko et al. 2002), giving a total of 8,516 ORFs. Whereas oligonucleotides for 8,516 ORFs were designed, 63 ORFs derived from the original annotation were excluded before printing the DNA microarray slides due to the lack of suitable unique probes. Consequently, the final arrays contained 8,453 predicted ORFs from the $B$. japonicum and 36 control genes.

Three different microarray experiments (discussed below) were used to determine whether these additional ORFs hybridized with a given cDNA. Because the array was constructed on a two-color (cy3 and cy5) basis, a higher than background intensity in either the cy3 or cy 5 channel indicated the presence of a transcript. Thus, the sum of cy 3 and cy5 intensities for each ORF was plotted in the order of intensity strength (Fig. 1). As a threshold, the sum of mean background intensities for cy3 and cy5 across the array was used. Most of the 199 newly annotated ORFs showed higher intensity than the background, with a few exceptions in the minimal versus rich medium comparison (Fig. 1A). However, those few ORFs not expressed appeared to be more greatly expressed in the osmotic and bacteroid microarray experiments (Fig. 1B and C), suggesting that all of the 199 ORFs added to the annotation are most likely transcribed genes.
Validation of microarray experiments.

In order to validate the DNA microarray results, the expression of a number of genes found to be up- or downregulated in bacteroids also was measured by using quantitative reversetranscription polymerase chain reaction (qRT-PCR). The genes
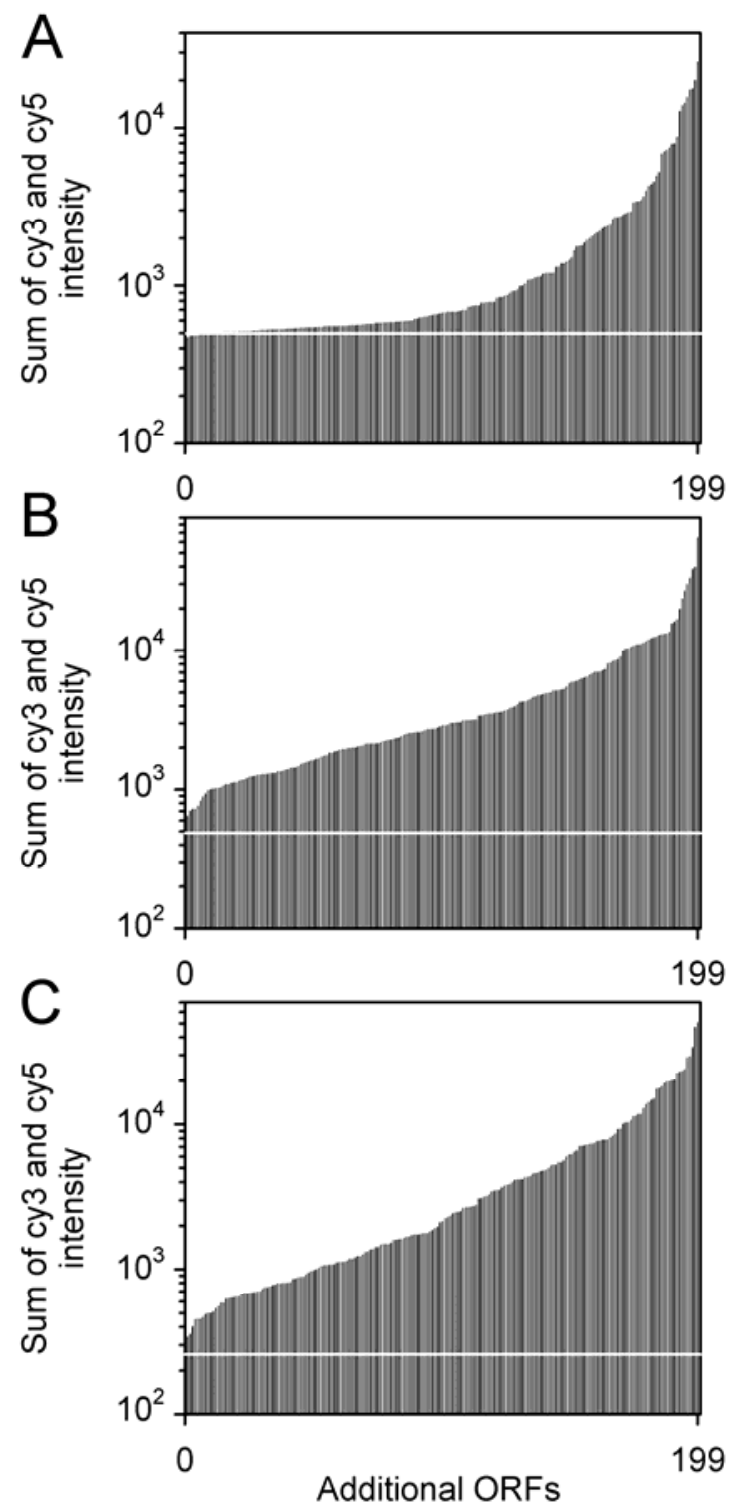

Fig. 1. Distribution of intensity values of 199 additional open reading frames (ORFs). Intensity was calculated from the sum of cy3 (532-nm channel) and cy5 (635-nm channel) intensity for each ORF. White lines indicate the sum of mean background intensities for cy 3 and cy5 across the array. Background intensity values (mean \pm standard deviation) are $497 \pm 30,473 \pm 63$, and $222 \pm 23$ for $\mathbf{A}$, minimal versus rich medium; $\mathbf{B}$, osmotic stress; and $\mathbf{C}$, free-living cells versus bacteroids, respectively.

Table 1. Gene-specific primers used for quantitative reverse-transcription polymerase chain reaction and corresponding amplicon size

\begin{tabular}{lllr}
\hline Locus & \multicolumn{1}{c}{ Forward primer } & \multicolumn{1}{c}{ Reverse primer } & Amplicon size (bp) \\
\hline blr1769 & ACCACTTCGCAGAACACGCT & TTGGCGTGCAGAATAAGGCGA & 107 \\
bl16939 & ACAATCGCATCCTGGTGCTCG & ATGGTGACGTTGTCAGGCACG & 115 \\
blr1746 & CAACTGCCTTCTCCCACCCAT & 80 \\
blr1744 & ACTCACAAAGTTGCCGCTCGT & AGCCCGTCGGTCATGTTGT & 99 \\
bl10735 & TTTGTCGCGGCACTTCAAGGA & ATCGCGCCGATGAAGCAGG & 103 \\
bl15813 & TCAAGCTCACCACGCCGAA & TATTTGACGTTGCCGGTCGCA & 81 \\
blr1812 & GATCAAGCCGGACCAGTCGAA & CGGACTTGCCAGCACATTCGT & 107 \\
blr1813 & TGGCGCAAGTAGCTCCCAAT & TTCCGTCCTTGGCGACAACA & 87 \\
blr1819 & AAATTCAGGAGCGCGAGGCT & AAAGGACGATGTTCGCGGT & 118 \\
bl12757 & CTTGGTCTCCTGGCCTTGCT & AGATCTCCTCGTCCTTGCGGT & 120 \\
\hline
\end{tabular}


listed in Table 1 were selected based on fold expression changes and functional categories. Overall qRT-PCR and microarray data were very consistent $\left(R^{2}=0.96\right)$ (Fig. 2$)$, although, in general, higher expression was seen using qRT-PCR, reflecting the greater sensitivity of the method (slope $=1.14$ ) (Barnett et al. 2004; Becker et al. 2004).

\section{Minimal versus rich medium.}

As the first test of the quality of the B. japonicum DNA microarrays, we profiled transcription of cells grown in minimal versus rich medium. These contrasting conditions were chosen for two reasons: i) they were likely to show a significant difference in gene expression (Tao et al. 1999) and ii) changes in nutritional status is one of the major environmental cues that $B$. japonicum often faces in soils and the rhizosphere.

One measure of array quality is spot hybridization efficiency. In this initial experiment, $15,580(92.2 \%)$ of 16,906 spots $(8,453$ genes with two technical replicates) showed intensity values above background in at least four of six replicates (three biological replicates with dye swap). This high sensitivity of the $B$. japonicum DNA microarrays indicates that they are a reliable tool for high-throughput functional genomic studies of $B$. japonicum. Similar results were obtained for $S$. meliloti microarrays (91.3 and 97.3\%) (Ruberg et al. 2003).

The similarity of the technical replicates on the arrays also was evaluated. To rule out possible dye effects and biological variation, we examined each array separately (Supplemental Fig.1). Ratios of duplicate spots were very consistent within the same array, indicating that these technical replicates provide more statistical confidence and, hence, a reliable gene expression profile is expected from the array.

A total of 656 genes were differentially expressed at a twofold cut-off: 351 genes (4.1\% of the genome) and 305 genes (3.6\% of the genome) were significantly induced in minimal and rich medium, respectively (Table 2). Similarly, expression analysis of Escherichia coli showed that 5.2 and $2.8 \%$ of the total genome were induced in minimal and rich medium (Tao et al. 1999), respectively. These results indicate that more genes are upregulated in nutrient-limited environments. In $S$. meliloti, more genes were differentially regulated when the carbon source was glucose $(13 \%$ of the $6,207 \mathrm{~S}$. meliloti

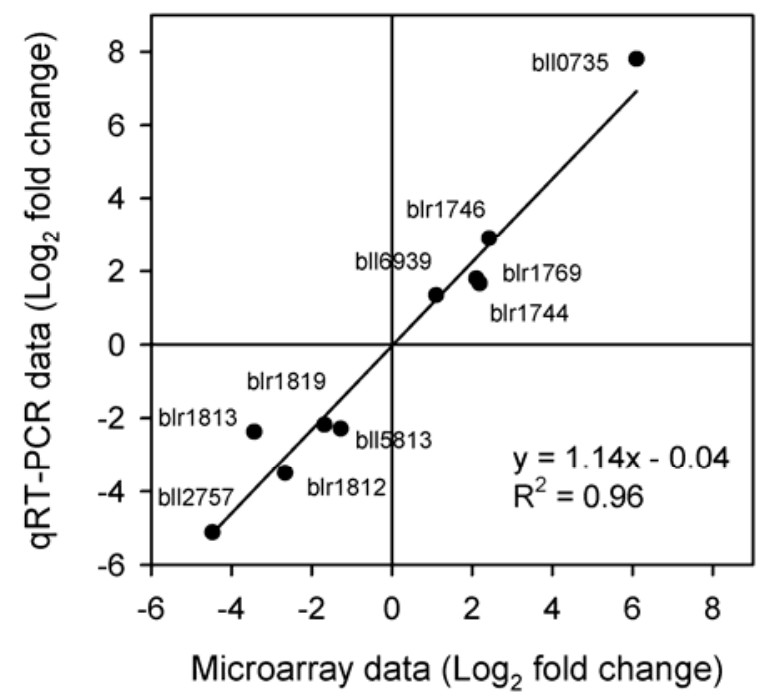

Fig. 2. Correlation between microarray and quantitative reverse-transcription polymerase chain reaction (qRT-PCR) data of the free-living versus bacteroid experiment for 10 genes. These genes were chosen based on fold induction and functional categories. Expression differences were $\log _{2}$ transformed. genes) compared with succinate (8\% of the genome) (Barnett et al. 2004), and Affymetrix chip analysis of succinate-grown $S$. meliloti revealed five times more changes in gene expression than a PCR-based microarray of the cells grown in the same carbon source, although a different minimal medium was used in these studies (M9 and Vincent's minimal medium, respectively) (Barnett et al. 2004; Becker et al. 2004).

One obvious expectation in a gene expression comparison between cells growing in minimal and rich medium would be an increased demand for protein translation machinery (e.g., ribosomal proteins) required for the faster growth in rich medium (Tao et al. 1999). As expected, 29 translation-related genes were expressed higher in rich medium than in minimal medium, the majority of which were ribosomal proteins. In contrast, although eight translation-related genes were more highly expressed in cells growing in minimal medium, none of them were ribosomal proteins (Table 2; Supplemental Table 2). This result is consistent with a previous study showing that approximately $80 \%$ of the total genes encoding ribosomal proteins are induced in $E$. coli cells grown in rich medium (Tao et al. 1999). However, higher transcript levels of the genes encoding ribosomal proteins were not observed in a transcriptional profile of $S$. meliloti growing in rich medium compared with minimal medium (Barnett et al. 2004; Becker et al. 2004), suggesting that regulation of the translation apparatus is different among rhizobia (at least between $B$. japonicum and $S$. meliloti) when they encounter fluctuations of nutrient availability.

$B$. japonicum grown in minimal medium is likely to suffer from a lack of cofactors and prosthetic groups due to nutrient limitation. To overcome this stressful situation, cells need to biosynthesize these molecules when grown in minimal medium. Twenty genes encoding cofactor biosyntheses were expressed higher in minimal medium, whereas none were expressed higher in rich medium (Table 2). Among these were genes related to vitamin biosyntheses: blr2095 (bioB), blr2097 (bioF), and blr2098 (bioD) for biotin synthesis; bll5475 to bll5478 for folic acid synthesis; and bsr6656 to blr6659 (thiSGEC) involved in thiamine synthesis (Table 2). In contrast to our findings, comparisons of $S$. meliloti grown in minimal versus rich medium (Barnett et al. 2004) did not show a comparable upregulation of vitamin biosynthetic genes.

It is well documented that vitamin limitation influences rhizobial growth in the rhizosphere (Streit et al. 1996), suggesting that the rhizosphere may represent a nutrient-limiting environment. Several vitamin auxotrophs (i.e., biotin, thiamine, and cobalamin) unable to grow in minimal medium either failed to establish a symbiosis with their hosts or formed ineffective nodules. Exogenous application of vitamins to these mutants restored effective nodule formation (Campbell et al. 2006; Schwinghamer 1970).

In addition to cofactor biosynthesis, a variety of other known stress-inducible genes were upregulated in minimal medium. Four genes were induced in minimal medium: bsr3154 ( $\operatorname{sp} A)$ and bs18249 ( $\operatorname{csp} A)$, both encoding cold-shock proteins; bll0729 ( $h s p H)$, encoding a small heat-shock protein; and blr7337 (rpoH2), encoding a $\sigma^{32}$-like transcription factor. However, no stress-inducible genes were observed in rich medium. This is consistent with gene expression in $E$. coli that revealed increased expression of the sigma factors $r p o S$ and $r p o E$, and the global regulator $d p s$ in minimal medium (Tao et al. 1999). However, there were almost equal numbers of twocomponent regulatory genes differentially expressed in both culture conditions (Table 2). Similarly, the expression of genes encoding transporter proteins showed no bias toward growth in either minimal or rich medium (Table 2).

Interestingly, the expression of 27 flagella and chemotaxis biosynthetic genes significantly increased in rich medium, indi- 
cating that motility functions of the faster-growing cells were activated (Table 2). Because energy for flagellar rotation is known to be derived from a proton motive force (Larsen et al. 1974; Manson et al. 1977), nutrient-rich conditions are conducive to the expression of motility. It has been suggested that cells shut off their motility function and thereby save energy in nutrientpoor conditions (White 2000a). Recently, transcriptional profiling of $S$. meliloti revealed that motility-related genes represented $25 \%$ of the 250 genes whose expression decreased in minimal medium (Barnett et al. 2004), which is in agreement with our findings. Unlike B. japonicum and S. meliloti, the flagellar motility apparatus of $E$. coli is not repressed in minimal medium (Tao et al. 1999).

Taken together, the overall transcriptional profile of $B$. japonicum grown in minimal versus rich medium differed significantly from the published studies of $S$. meliloti, except for genes involved in flagella and chemotaxis biosynthesis. Therefore, these two rhizobia may differ significantly in the way in which they respond to nutrient limitation.

\section{Osmotic stress.}

It is known that $B$. japonicum is very sensitive to osmotic stress, which is encountered in the soil, rhizosphere, and in planta environment (Boncompagni et al. 1999; Elsheikh and
Wood 1990). To characterize the osmotic stress response in $B$. japonicum, we analyzed the transcriptome upon exposure to $50 \mathrm{mM} \mathrm{NaCl}$. B. japonicum did not grow in medium supplemented with $100 \mathrm{mM} \mathrm{NaCl}$ (Boncompagni et al. 1999), but grew at $50 \mathrm{mM} \mathrm{NaCl}$ with a reduced growth rate and final cell density (data not shown), suggesting that the osmotic conditions caused significant stress to growing B. japonicum cells.

Among 441 differentially expressed genes (1.5-fold cut-off), 269 were induced and 172 were repressed by $\mathrm{NaCl}$ treatment (Table. 3). A 2-fold cut-off was applied initially, but numerous genes whose expression level increased between 1.5- and 1.9fold were located in operons or gene clusters with other genes induced 2-fold or higher (e.g., flagella and chemotaxis) (Supplemental Table 3), suggesting that all these genes should be considered as being differentially expressed.

One of the well-known bacterial responses to increased osmolarity is the accumulation of intracellular compatible solutes, such as $\mathrm{K}^{+}$, amino acids (e.g., glutamate), carbohydrates (e.g., trehalose), and osmoprotectants such as ectoine, glycine betaine, and choline. The latter compounds act as nontoxic cytoplasmic co-solvents whose level can be modulated by de novo synthesis or transport from the environment (Boncompagni et al. 1999; Csonka 1989; Wood 1999). No genes involved in

Table 2. Functional group assignment of a subset of Bradyrhizobium japonicum genes differentially expressed in response to rich medium

\begin{tabular}{|c|c|c|c|c|}
\hline \multirow[b]{2}{*}{ Locus (gene) } & \multirow[b]{2}{*}{ Fold change $^{c}$} & \multirow[b]{2}{*}{ Functional groups and annotation ${ }^{d}$} & \multicolumn{2}{|c|}{ Number of genes ${ }^{b}$} \\
\hline & & & Up & Down \\
\hline & & Biosynthesis of cofactors, prosthetic groups, and carriers & 0 & 20 \\
\hline blr3954 ( $m m s A)$ & -11.1 & Methylmalonate-semialdehyde dehydrogenase & $\ldots$ & $\ldots$ \\
\hline bsr6656 (thiS) & -4.4 & Thiamine biosynthesis protein homolog & $\ldots$ & $\ldots$ \\
\hline blr6658 (thiE) & -2.4 & Thiamine-phosphate pyrophosphorylase & $\ldots$ & $\ldots$ \\
\hline blr2095 (bioB) & -2.2 & Biotin synthetase & $\ldots$ & $\ldots$ \\
\hline bl15476 & -7.3 & Formate dehydrogenase iron-sulfur subunit & $\ldots$ & $\ldots$ \\
\hline \multirow[t]{2}{*}{ bl10751 (trxA) } & -2.1 & Thioredoxin C-1 & $\ldots$ & $\ldots$ \\
\hline & & Cellular processes & 37 & 6 \\
\hline bll4326 & 3.2 & Putative methyl-accepting chemotaxis protein & $\ldots$ & $\ldots$ \\
\hline bll1438 (ctpE) & 3.0 & Pilus assembly protein & $\ldots$ & $\ldots$ \\
\hline blr5830 $(f \lg H)$ & 4.1 & Flagellar L-ring protein precursor & $\ldots$ & $\ldots$ \\
\hline bl15812 (fliE) & 2.7 & Flagellar hook-basal body complex protein & $\ldots$ & $\ldots$ \\
\hline bll2207 (flhA) & 3.2 & Flagellar biosynthesis protein & $\ldots$ & $\ldots$ \\
\hline blr5828 $(f \lg G)$ & 5.0 & Flagellar basal-body rod protein & $\ldots$ & $\ldots$ \\
\hline blr2506 & 2.8 & Putative chemotaxis protein & $\ldots$ & $\ldots$ \\
\hline bl10667 (ctpC) & 2.3 & CtpC protein & $\ldots$ & $\ldots$ \\
\hline \multirow[t]{2}{*}{ blr2192 (cheA) } & 2.2 & Chemotaxis two-component hybrid sensor and regulator & $\ldots$ & $\ldots$ \\
\hline & & Translation & 29 & 8 \\
\hline blr0740 (rpsA) & 2.0 & $30 \mathrm{~S}$ ribosomal protein $\mathrm{S} 1$ & $\ldots$ & $\ldots$ \\
\hline blr0482 (rpsP) & 3.0 & $30 \mathrm{~S}$ ribosomal protein $\mathrm{S} 16$ & $\ldots$ & $\ldots$ \\
\hline bs10832 (rpsT) & 2.1 & $30 \mathrm{~S}$ ribosomal protein $\mathrm{S} 20$ & $\ldots$ & $\ldots$ \\
\hline bl14963 (rplM) & 3.3 & 50 S ribosomal protein $\mathrm{L} 13$ & $\ldots$ & $\ldots$ \\
\hline bl15397 (rplB) & 2.2 & $50 \mathrm{~S}$ ribosomal protein $\mathrm{L} 2$ & $\ldots$ & $\ldots$ \\
\hline bs10708 (rpmI) & 2.2 & $50 \mathrm{~S}$ ribosomal protein $\mathrm{L} 35$ & $\ldots$ & $\ldots$ \\
\hline \multirow[t]{14}{*}{ bll4386 (efp) } & 3.2 & Elongation factor $\mathrm{P}$ & $\ldots$ & $\ldots$ \\
\hline & $\ldots$ & Amino acid biosynthesis & 5 & 8 \\
\hline & $\ldots$ & Cell envelope (lipoproteins, porins, polysaccharides, etc.) & 11 & 2 \\
\hline & $\ldots$ & Central intermediary metabolism & 4 & 8 \\
\hline & $\ldots$ & DNA replication, recombination, and repair & 3 & 1 \\
\hline & $\ldots$ & Energy metabolism & 18 & 19 \\
\hline & $\ldots$ & Fatty acid, phospholipid and sterol metabolism & 2 & 12 \\
\hline & $\ldots$ & Purines, pyrimidines, nucleosides, and nucleotides & 3 & 2 \\
\hline & $\ldots$ & Regulatory functions & 11 & 10 \\
\hline & $\ldots$ & Transcription & 3 & 1 \\
\hline & $\ldots$ & Transport and binding proteins; & 26 & 26 \\
\hline & $\ldots$ & Other categories & 21 & 58 \\
\hline & $\ldots$ & Hypothetical protein & 132 & 170 \\
\hline & & Total & 305 & 351 \\
\hline
\end{tabular}

a Differentially expressed genes were selected based on twofold cut off with $q$ value $\leq 0.05$.

${ }^{\mathrm{b}}$ Genes upregulated in rich medium are the same as those downregulated in minimal medium, and vice versa.

${ }^{\mathrm{c}}$ Positive and negative values indicate up- and downregulation in response to rich medium compared with minimal medium, respectively.

${ }^{\mathrm{d}}$ Functional groups and annotations (gene description) represent the first and third levels, respectively, among three different levels based on the RhizoBase annotation. 
de novo synthesis of glutamate and trehalose were found to be upregulated in response to growth in $50 \mathrm{mM} \mathrm{NaCl}$ (Table 3). This suggests that minimally salt-stressed bradyrhizobial cells might preferentially utilize transporter systems under these conditions to accumulate compatible solutes or osmoprotectants. Although 14 genes encoding transport proteins were induced in these conditions, none belonged to known potassium and osmoprotectant uptake systems (Table 3). However, we cannot rule out the possibility that a novel transport system among the 14 upregulated genes may play a role in the osmotic response.

Analysis of $B$. japonicum USDA110 genome revealed no similarity to the ectoine, glycine betaine, and betaine choline carnitine transporter (BCCT) systems (Boscari et al. 2004; Kaneko et al. 2002), the latter of which was characterized in $S$. meliloti. The lack of such systems may explain the increased salt sensitivity of B. japonicum compared with other rhizobia. Interestingly, functional expression of the $S$. meliloti BCCT system in B. japonicum improved cell viability up to $80 \mathrm{mM}$ $\mathrm{NaCl}$ in the presence of glycine betaine, but could not overcome the deleterious effects of $100 \mathrm{mM} \mathrm{NaCl}$, despite an accumulation of glycine betaine inside cells (Boscari et al. 2004).

In contrast to the lack of evidence supporting the accumulation of compatible solutes, 13 stress-related genes, including blr4635 (mopA), blr4637 (hsp), blr4653 (dnaJ), blr7740, blr7961, bsl8249 (cpsA), bll1167 (sipS), blr7337 (rpoH2), blr2591 (dop), blr3130 (htrA), blr7484, blr7485, and bll1168 $(t l d D)$, were induced up to sevenfold in response to osmotic stress (Table 3), indicating the involvement of a number of stress-related genes in osmoadaptation. Interestingly, four genes encode heat- or cold-shock proteins, suggesting an overlapping adaptation in response to different environmental stressors. In addition $\mathrm{rpoH} 2$, encoding a $\sigma^{32}$-like transcription factor, was induced in conditions of osmotic stress and growth in minimal medium (Table 3 ). This further suggests that $\mathrm{rpoH} 2$ may play a key role in the global stress responses of $B$. japonicum. The majority of these genes, except $r p o H 2$, previously were unidentified in microarray analyses of the osmotic stress response in $S$. meliloti (Dominguez-Ferreras et al. 2006), although some osmotic stress-inducible genes encoding heat- and cold-shock pro-

Table 3. Functional group assignments of a subset of genes differentially expressed in response to $\mathrm{NaCl}$ treatment ${ }^{\mathrm{a}}$

\begin{tabular}{|c|c|c|c|c|}
\hline \multirow[b]{2}{*}{ Locus (gene) } & \multirow[b]{2}{*}{ Fold change $^{b}$} & \multirow[b]{2}{*}{ Functional groups and annotation ${ }^{\mathrm{c}}$} & \multicolumn{2}{|c|}{ Number of genes } \\
\hline & & & Up & Down \\
\hline & & Cellular processes & 7 & 34 \\
\hline blr4635 (mopA) & 2.1 & Chaperonin GroEL & $\ldots$ & $\ldots$ \\
\hline blr4637 (hsp) & 6.5 & Probable HspC2 heat-shock protein & $\ldots$ & $\ldots$ \\
\hline blr4653 (dnaJ) & 2.2 & Molecular chaperone DnaJ family & $\ldots$ & $\ldots$ \\
\hline blr7740 & 1.5 & Small heat-shock protein & $\ldots$ & $\ldots$ \\
\hline blr7961 & 1.9 & Probable HspC2 heat shock protein & $\ldots$ & $\ldots$ \\
\hline bs18249 (cspA) & 1.8 & Cold-shock protein & $\ldots$ & $\ldots$ \\
\hline bl10096 & -1.6 & Putative methyl accepting chemotaxis & $\ldots$ & $\ldots$ \\
\hline bll1438 (ctpE) & -2.3 & Pilus assemble protein & $\ldots$ & $\ldots$ \\
\hline bl15813 (flgC) & -2.0 & Flagellar basal-body rod protein & $\ldots$ & $\ldots$ \\
\hline bll6865 (fla) & -2.7 & Flagellin & $\ldots$ & $\ldots$ \\
\hline blr2344 (cheWII) & -1.6 & Probable chemotaxis protein & $\ldots$ & $\cdots$ \\
\hline \multirow{3}{*}{ bll1167 (sipS) } & \multirow[b]{2}{*}{1.6} & Central intermediary metabolism & 12 & 2 \\
\hline & & Signal peptidase & $\ldots$ & $\ldots$ \\
\hline & \multirow{3}{*}{2.1} & Transcription & 1 & 1 \\
\hline \multirow[t]{2}{*}{ blr7337 (rpoH2) } & & sigma32-like transcription factor & $\ldots$ & $\ldots$ \\
\hline & & Translation & 4 & 10 \\
\hline blr2591 (dop) & 3.1 & Serine protease DO-like protease & $\ldots$ & $\ldots$ \\
\hline blr3130 (htrA) & 2.8 & Serine protease DO-like precursor & $\ldots$ & $\ldots$ \\
\hline blr7484 & 2.0 & Hypothetical zinc protease & $\ldots$ & $\ldots$ \\
\hline \multirow[t]{2}{*}{ blr7485 } & 1.8 & Hypothetical zinc protease & $\ldots$ & $\ldots$ \\
\hline & & Transport and binding proteins & 14 & 12 \\
\hline bl17103 & 1.8 & $\mathrm{ABC}$ transporter permease protein & $\ldots$ & $\ldots$ \\
\hline bll7988 & 1.9 & Probable ATP-binding protein & $\ldots$ & $\ldots$ \\
\hline blr2622(corA) & 2.8 & Magnesium/cobalt transport protein & $\ldots$ & $\ldots$ \\
\hline blr7037 (napD) & 4.5 & Periplasmic nitrate reductase & $\ldots$ & $\ldots$ \\
\hline blr6149 & -1.6 & $\mathrm{ABC}$ transporter permease protein & $\ldots$ & $\ldots$ \\
\hline blr7827 & -1.5 & $\mathrm{ABC}$ transporter substrate-binding protein & $\ldots$ & $\ldots$ \\
\hline blr7824 & -1.5 & ABC-transporter ATP-binding protein & $\ldots$ & $\ldots$ \\
\hline \multirow[t]{10}{*}{ blr0607 } & -1.8 & Probable ammonium transporter & $\ldots$ & $\ldots$ \\
\hline & $\ldots$ & Amino acid biosynthesis & 1 & 3 \\
\hline & $\ldots$ & Biosynthesis of cofactors, prosthetic groups, and carriers & 2 & 0 \\
\hline & $\ldots$ & Cell envelope & 5 & 8 \\
\hline & $\ldots$ & DNA replication, recombination, and repair & 0 & 1 \\
\hline & $\ldots$ & Energy metabolism & 12 & 7 \\
\hline & $\ldots$ & Fatty acid, phospholipid and sterol metabolism & 4 & 0 \\
\hline & $\ldots$ & Purines, pyrimidines, nucleosides, and nucleotides & 1 & 1 \\
\hline & $\ldots$ & Regulatory functions & 17 & 6 \\
\hline & & Other categories & 20 & 8 \\
\hline \multirow[t]{3}{*}{ bl11168 (tldD) } & 1.7 & TldD protein & $\ldots$ & $\cdots$ \\
\hline & & Hypothetical protein & 169 & 79 \\
\hline & & Total & 269 & 172 \\
\hline
\end{tabular}

${ }^{\text {a }}$ Differentially expressed genes were selected based on 1.5 -fold cut-off with $q$ value $\leq 0.05$.

${ }^{\mathrm{b}}$ Positive and negative values indicate up- and downregulation, respectively, in response to osmotic stress.

${ }^{\mathrm{c}}$ Functional groups and annotations (gene description) represent the first and third levels, respectively, among three different levels based on the RhizoBase annotation. Stress-related genes are indicated in italics. 
teins were observed for Bacillus subtilis (Budde et al. 2006) and Pseudomonas aeruginosa (Aspedon et al. 2006). These results indicate that Bradyrhizobium japonicum may use these stressresponsive genes to compensate for the lack of compatible solute or osmoprotectant accumulation. However, these genes seem more likely to function only in a mild osmotic stress response due to the fact that $B$. japonicum did not grow at a $\mathrm{NaCl}$ concen- tration above $100 \mathrm{mM}$ (Boncompagni et al. 1999). In fact, the lack of glycine betaine and chlorine uptake systems suggests that $B$. japonicum behaves in a different manner when encountering osmotic stress compared with other osmotolerant rhizobia. From an inoculant perspective, it will be important to identify and characterize genes whose expression can improve cell survival during osmotic stress.

Table 4. Functional group assignments of genes differentially expressed in bacteroids ${ }^{\mathrm{a}}$

\begin{tabular}{|c|c|c|c|c|}
\hline \multirow[b]{2}{*}{ Locus (gene) } & \multirow[b]{2}{*}{ Fold change $^{b}$} & \multirow[b]{2}{*}{ Functional groups and annotation ${ }^{c}$} & \multicolumn{2}{|c|}{ Number of genes } \\
\hline & & & Up & Down \\
\hline & & Central intermediary metabolism & 31 & 23 \\
\hline blr1744 (nifK) & 4.5 & Nitrogenase molybdenum-iron protein $\beta$ chain & $\ldots$ & $\ldots$ \\
\hline blr1745 (nifE) & 7.0 & Nitrogenase molybdenum-cofactor synthesis protein & $\ldots$ & $\ldots$ \\
\hline blr1746 (nifN) & 5.5 & Nitrogenase molybdenum-cofactor synthesis protein & $\ldots$ & $\ldots$ \\
\hline blr1747 (nifX) & 5.1 & Iron-molibdenum cofactor processing protein & $\ldots$ & $\ldots$ \\
\hline blr1761 (nifZ) & 4.3 & Iron-sulfur cofactor synthesis protein & $\ldots$ & $\ldots$ \\
\hline blr1773 (fixB) & 2.6 & Electron transfer flavoprotein $\alpha$ chain & $\ldots$ & $\ldots$ \\
\hline blr1774 (fixC) & 4.3 & Flavoprotein & $\ldots$ & $\ldots$ \\
\hline bsr1757 (fixU) & 3.0 & Nitrogen fixation protein (fixU) & $\ldots$ & $\ldots$ \\
\hline bsr1775 (fixX) & 5.1 & Probable ferredoxin & $\ldots$ & $\ldots$ \\
\hline blr1724 (hupD) & 2.8 & HupD protein homolog, hupD C-terminal & $\ldots$ & $\ldots$ \\
\hline blr1727 (hирH) & 5.4 & HupH protein homolog & $\ldots$ & $\ldots$ \\
\hline blr1728 (hupK) & 4.7 & HupK protein homolog, hupK N-terminal & $\ldots$ & $\ldots$ \\
\hline bs16935 (hupI) & 2.0 & HupI protein & $\ldots$ & $\ldots$ \\
\hline bl16939 (hupD) & 2.2 & HupD protein & $\ldots$ & $\ldots$ \\
\hline bl12757 (fixK2) & -23.7 & Transcriptional regulatory protein & $\ldots$ & $\ldots$ \\
\hline blr2763 (fixN) & -4.2 & Cytochrome c oxidase & $\ldots$ & $\ldots$ \\
\hline blr2764 (fixO) & -2.3 & Cytochrome $\mathrm{c}$ oxidase & $\ldots$ & $\ldots$ \\
\hline \multirow[t]{2}{*}{ bsr2765 (fixQ) } & -2.4 & cbb3 oxidase subunit IV & $\ldots$ & $\ldots$ \\
\hline & & Cellular processes & 16 & 31 \\
\hline blr2144 & 2.5 & Cytochrome P-450 BJ-1 & $\ldots$ & $\ldots$ \\
\hline blr2145 & 3.9 & Cytochrome P-450 BJ-3 & $\ldots$ & $\ldots$ \\
\hline blr2147 & 6.3 & Cytochrome P-450 BJ-4 & $\ldots$ & $\ldots$ \\
\hline blr 1853 & 21.0 & Cytochrome P450 family protein & $\ldots$ & $\ldots$ \\
\hline bl16537 & 2.8 & Putative cytochrome P-450 & $\ldots$ & $\ldots$ \\
\hline bl11800 (rhcV) & -2.1 & $\mathrm{RhcV}$ protein & $\ldots$ & $\ldots$ \\
\hline blr1813(rhcJ) & -10.9 & RhcJ protein & $\ldots$ & $\ldots$ \\
\hline blr1816 $(r h c N)$ & -2.0 & RhcN protein & $\ldots$ & $\ldots$ \\
\hline blr1818 (rhcQ) & -4.0 & RhcQ protein & $\ldots$ & $\ldots$ \\
\hline \multirow[t]{2}{*}{ blr1819 (rhcR) } & -3.3 & RhcR protein & $\ldots$ & $\ldots$ \\
\hline & & Energy metabolism & 15 & 35 \\
\hline blr1171 ( $\operatorname{cox} A)$ & -2.1 & Cytochrome $\mathrm{C}$ oxidase subunit I & $\ldots$ & $\ldots$ \\
\hline blr1378 (etfL) & -5.9 & Electron transfer flavoprotein large subunit & $\ldots$ & $\ldots$ \\
\hline blr7544 (cycA) & -2.9 & Cytochrome c550 & $\ldots$ & $\ldots$ \\
\hline bl15913 (cycC) & -2.7 & Cytochrome C & $\ldots$ & $\ldots$ \\
\hline \multirow[t]{12}{*}{ blr1656 } & -10.2 & Endoglucanase & $\ldots$ & $\ldots$ \\
\hline & $\ldots$ & Amino acid biosynthesis & 5 & 14 \\
\hline & $\ldots$ & Biosynthesis of cofactors, prosthetic groups, and carriers & 10 & 6 \\
\hline & $\ldots$ & Cell envelope & 7 & 18 \\
\hline & $\ldots$ & DNA replication, recombination, and repair & 8 & 3 \\
\hline & $\ldots$ & Fatty acid, phospholipid and sterol metabolism & 8 & 9 \\
\hline & $\ldots$ & Purines, pyrimidines, nucleosides, and nucleotides & 4 & 8 \\
\hline & $\ldots$ & Regulatory functions & 55 & 20 \\
\hline & $\ldots$ & Transcription & 8 & 0 \\
\hline & $\ldots$ & Translation & 7 & 23 \\
\hline & $\ldots$ & Transport and binding proteins & 22 & 40 \\
\hline & & Other categories (e.g., symbiosis, transposon, etc.) & 84 & 75 \\
\hline bs12015 (nolZ) & 8.4 & NolZ protein & $\ldots$ & $\ldots$ \\
\hline bl12016 (nolY) & 2.8 & NolY protein & $\ldots$ & $\ldots$ \\
\hline blr2062 (noel) & 3.3 & Nodulation protein & $\ldots$ & $\ldots$ \\
\hline \multirow[t]{2}{*}{ blr1752 } & -6.3 & similar to NopP & $\ldots$ & $\ldots$ \\
\hline & & Hypothetical protein & 381 & 268 \\
\hline blr1649 & -7.3 & Unknown & $\ldots$ & $\ldots$ \\
\hline blr1806 & -10.6 & Similar to blr1806 (77\% identity) & $\ldots$ & $\ldots$ \\
\hline \multirow[t]{2}{*}{ blr1862 } & -5.7 & Unknown & $\ldots$ & $\ldots$ \\
\hline & & Total & 661 & 573 \\
\hline
\end{tabular}

${ }^{\text {a }}$ Differentially expressed genes were selected based on twofold cut-off with $q$ value $\leq 0.05$.

${ }^{\mathrm{b}}$ Positive and negative values indicate up- and downregulation, respectively, in bacteroids.

${ }^{\mathrm{c}}$ Functional groups and annotations (gene description) represent the first and third levels, respectively, among three different levels based on the RhizoBase annotation. Italic letters indicate proteins that are likely to be secreted through a Bradyrhizobium japonicum type III secretion system (TTSS) induced by genistein. Annotation in italic letters was adopted from the previous study (Suss et al. 2006). Rhc proteins belong to B. japonicum TTSS machinery. 
Consistent with downregulation of chemotaxis- and flagellarelated genes by salt stress in Shewanella oneidensis MR-1 (Liu et al. 2005), Bacillus subtilis (Budde et al. 2006), and Sinorhizobium meliloti (Ruberg et al. 2003), the expression of 29 genes encoding motility proteins decreased in the presence of $50 \mathrm{mM}$ $\mathrm{NaCl}$ (Table 3). Furthermore, functional analyses indicated that Bradyrhizobium japonicum had reduced motility in the presence of $50 \mathrm{mM} \mathrm{NaCl}$ (data not shown). This appears to be a general bacterial response to $\mathrm{NaCl}$. E. coli, Shewanella oneidensis, and Bacillus subtilis all showed decreased motility when grown under conditions of high salinity (Li et al. 1993; Liu et al. 2005; Steil et al. 2003). The repression of motility may represent a strategy to survive a stressful condition by allowing for energy conservation to possibly produce stress-related proteins.

\section{Free-living cells grown in rich medium versus bacteriods.}

To address gene expression changes in the symbiotic state, we compared transcript levels between cultured cells and bacteroids. A total of 1,234 genes, representing approximately $15 \%$ of the genome, were differentially expressed at a twofold cut-off. In bacteroids, expression of 661 and 573 genes were induced and repressed, respectively, relative to those in freeliving conditions (Table 4). Recent transcriptional profiling studies of Sinorhizobium meliloti showed that $63 \%$ more genes were downregulated in bacteroids than upregulated (up, 345 genes; down, 943 genes) (Barnett et al. 2004). In contrast, there were $74 \%$ more upregulated genes in the transcriptome of M. loti bacteroids than in free-living cells (up, 99; down, 26), although a more stringent fold cut-off (20-fold) was used compared with that used for Bradyrhizobium japonicum and $S$. meliloti (Uchiumi et al. 2004).

As expected, 22 genes involved in nitrogen fixation were highly induced in the bacteroid state (Table 4; Supplemental Table 4). Numerous nif and fix genes, but not all, appeared to be upregulated in bacteroids. This result is consistent with microarray studies done using $S$. meliloti and $M$. loti bacteroids (Barnett et al. 2004; Becker et al. 2004; Uchiumi et al. 2004). Genes involved in hydrogen uptake also were upregulated (Table 4), supporting the notion that B. japonicum recycles hydrogen molecules generated by nitrogenase activity to increase nitrogen fixation efficiency (White 2000b). Unexpectedly, several nodulation genes-bsl2015 (nolZ), bll2016 (nolY), blr2027 (nodC), blr2062 (noeI), and blr2073 (noeE) - also were induced up to eightfold in bacteroids. Perhaps this result is not surprising, because expression of 10 nodulation genes also was found to be induced in S. meliloti bacteroids (Becker et al. 2004). It will be interesting to ascertain if these genes possess a secondary function involved in bacteroid differentiation or metabolism.

Given the sensitivity of all nitrogenases to oxygen, the nodule environment is relatively microaerobic. Despite oxygen limitation in bacteroids, four genes encoding for cytochrome P-450 enzymes, which function to bind and activate oxygen for transfer (Appleby et al. 1975; Keister et al. 1999), appeared to be induced up to 21-fold in bacteroids (Table 4). B. japonicum bacteroids may utilize these enzymes for respiration under the oxygen-limited conditions. These results paradoxically suggest that, although free oxygen in nodules is low $(18 \mathrm{nM}$ ) (Layzell et al. 1990), cytochromes P-450 facilitate sufficient electron transfer through their high $\mathrm{O}_{2}$ affinity for respiration to generate energy, which eventually is consumed for nitrogen fixation. A mutant study of cytochromes P-450, however, showed no defect in symbiosis phenotype (Tully and Keister 1993), suggesting that the $\mathrm{P}-450$ s are not essential in symbiotic function, but rather play a role in microaerobic environments (Daniel and Appleby 1972). Alternately, the cytochrome P-450s may be using an alternate electron acceptor in the bacteroid state.
Interestingly, a number of transcriptional regulatory genes, including two-component response regulators, were differentially expressed in bacteroids and, of these, 55 genes were upregulated and 20 genes were downregulated. The expression of more regulatory genes in nodules suggests that the plant environment is more complex than that found in laboratory culture medium. More interestingly, the greatest decrease ( -23.7 fold) in gene expression was observed for bll2757 ( fix $_{2}$ ) whose product is known to play a crucial role in the FixLJ-FixK $K_{2}$ regulatory network by positively regulating a large group of genes, including fix $K_{1}$, nnrR, hemABN $N_{1} N_{2}$, hupSL, fixNOQP, and fixGHIS, under anaerobic or microaerobic conditions (Fischer 1994; Hauser et al. 2006). Concomitant with the decreased expression of fix $K_{2}$, there was a corresponding decrease in gene expression of fixNOQ in bacteroids (Table 4). Conversely, a partial genome expression analysis of the B. japonicum symbiotic gene region revealed induction of fix $K_{2}(9.5-$ fold) and its associated genes under low oxygen conditions (Hauser et al. 2006). These contrasting results suggest that the nodule environment is quite different from the microoxic condition, although oxygen limitation is a characteristic of the former in the context of symbiosis. Thus, what is known about the regulation of genes under microaerobic conditions might not apply directly for genes expressed in bacteroids.

Transcriptional analyses revealed that 22 and 40 transportrelated genes were up- and downregulated, respectively, in bacteroids. Although many ABC transporter genes were identified, the decrease in expression of genes bll1800 ( $r h c V)$, blr1813 $(r h c J)$, blr1816 $(r h c N)$, blr1818 ( $r h c Q)$, and blr1819 (rhcR), whose products belong to the type III secretion system (TTSS), was of interest due to their importance for the establishment of the symbiosis with soybean. Mutational studies on the type III gene clusters (tts) of B. japonicum (Krause et al. 2002), Rhizobium sp. strain NGR234 (Viprey et al. 1998), and S. fredii (Bellato et al. 1997; Meinhardt et al. 1993) revealed that TTSS mutants are differentially affected in their ability to form nodules, depending on their host plants. Additionally, Krause and associates (2002) reported that a B. japonicum ttsI encoding the TtsI protein is essential for gene expression in the $t$ ts cluster and is activated by NodD1 and NodW in the presence of genistein, a soybean isoflavonoid which can induce nod gene expression. This suggests that a coordinated regulatory linkage between nod genes and the TTSS gene cluster may be important not only for Nod factor production but also for the secretion of extracellular proteins via the TTSS, leading to initiation of the reciprocal interaction between both partners. Indeed, Suss and associates (2006), using a proteomic approach, identified eight genisteininducible extracellular proteins in B. japonicum that likely are secreted by the TTSS. Interestingly, five of the genes (blr1649, blr1656, blr1752, blr1806, and bll1862) encoding these extracellular proteins also were shown to be downregulated up to 10fold in bacteroids (Table 4). This suggests that the secretion of extracellular proteins via the TTSS may play a role only during the initial phases of nodule initiation. In Rhizobium sp. strain NGR234, however, it is unclear whether TTSS genes are repressed in nodules, although both nod and TTSS genes are induced by flavonoids (Viprey et al. 1998).

\section{Conclusions.}

The purpose of this study was to develop and evaluate a relatively low-cost, whole-genome DNA microarray system for $B$. japonicum. The arrays are available to the public at cost and can be purchased by accessing our project website (Author-Recommended Internet Resources). The documented gene expression changes in B. japonicum under conditions of nutrient limitation and osmotic stress, and in the bacteroid state, illustrate that $B$. japonicum apparently responds differently from $S$. meliloti. This 
may be due, in part, to the fact that the B. japonicum-soybean symbiosis leads to the formation of determinate root nodules, whereas the host plants of $S$. meliloti develop indeterminate nodules. In addition, overall genome organization and physiology of the two microsymbionts differ greatly. Although it has been demonstrated that plant factors provoke bacteroid differentiation in cool-season legumes (e.g., Medicago spp.) (Mergaert et al. 2006), our findings suggest that the different fate of nodule development could be due to the bacterial genetic ability and regulatory network in response to different environmental conditions. For example, unlike $S$. meliloti, B. japonicum responds to nutrient limitation by reducing expression of the translational apparatus and increasing expression of vitamin biosynthesis in minimal medium. Analysis of the transcriptional response of $B$. japonicum to treatment with $\mathrm{NaCl}$ revealed a lack of expression of pathways for accumulation or synthesis of compatible solutes or osmoprotectants, as well as a lack of apparent transporters for the uptake of such compounds. Gene expression analysis of B. japonicum bacteroids revealed that, as expected, the majority of the nif genes were highly expressed. Curiously, regardless of the low-oxygen environment, cytochrome P-450 genes are expressed and presumably play a role in metabolism, although they are not essential based on previously published mutant studies (Tully and Keister 1993). The B. japonicum TTSS system is clearly repressed in bacteroids, suggesting that this system likely functions only during initial establishment of the symbiosis. Taken together, our results show that the developed microarrays are a useful tool for functional genomic studies, and likely will prove to be a valuable community resource for those who study this agriculturally important symbiotic bacterium.

\section{MATERIALS AND METHODS}

\section{Construction of the B. japonicum DNA microarray.}

A whole-genome DNA microarray for B. japonicum strain USDA110 was constructed starting from the genome sequence published by Kaneko and associates (2002). Before microarray construction, we reexamined the available sequence data to predict all possible ORFs. Gene models from GeneMark and Glimmer2 (Author-Recommended Internet Resources) were used to generate a nonoverlapping unique list of all predicted ORFs, and unique 70-mer oligonucleotides were designed and synthesized for each of the predicted ORFs by Operon Biotechnologies, Inc. (Huntsville, AL, U.S.A.). Oligonucleotides were printed onto Corning epoxy-coated slides (Corning Inc., Lowell, MA, U.S.A.) at the Washington University Genome Sequencing Center (St. Louis). Each slide contained 8,453 predicted ORFs from the B. japonicum genome annotation and 36 control genes, printed in duplicate. More detailed information about the array is available at our project website (Author-Recommended Internet Resources). Slides also can be ordered, for a modest cost, via this website.

\section{Bacterial growth and media.}

B. japonicum strain USDA110 was used in all microarray experiments. Cells were grown at $30^{\circ} \mathrm{C}$ with shaking at 200 $\mathrm{rpm}$, in minimal medium containing $0.3 \mathrm{~g}$ of $\mathrm{K}_{2} \mathrm{HPO}_{4}, 0.3 \mathrm{~g}$ of $\mathrm{KH}_{2} \mathrm{PO}_{4}, 0.5 \mathrm{~g}$ of $\mathrm{NH}_{4} \mathrm{NO}_{3}, 0.1 \mathrm{~g}$ of $\mathrm{MgSO}_{4} \cdot 7 \mathrm{H}_{2} \mathrm{O}, 0.05 \mathrm{~g}$ of $\mathrm{NaCl}, 4 \mathrm{ml}$ of glycerol, and $1 \mathrm{ml}$ of trace elements (Bishop et al. 1976) per liter of deionized water. Rich medium consisted of minimal medium amended with $0.5 \mathrm{~g}$ of yeast extract and 1 $\mathrm{ml}$ of vitamin stock (Bishop et al. 1976) per liter. For osmotic stress treatments, $50 \mathrm{mM} \mathrm{NaCl}$ was added to the rich medium. Cells grown in rich medium were used for free-living conditions, whereas bacteroids were harvested from nodulated plants as described below.

\section{Plant growth and bacteroid isolation.}

Soybean plants (Glycine max L. cv. Williams) were inoculated with $B$. japonicum USDA110, and grown in autoclaved Leonard jar assemblies containing a nitrogen-free nutrient solution (Karr et al. 1984). Seed were sown in equal parts of sand and vermiculite, both were washed thoroughly prior to planting, and plants were grown in the greenhouse with day and night temperatures of $28^{\circ} \mathrm{C}$ for $16 \mathrm{~h}$ and $20^{\circ} \mathrm{C}$ for $8 \mathrm{~h}$, respectively, and 48 to 90 Klux of light for day. Nodules from 4week-old plants were removed from the roots and immediately placed in ice water, and bacteroids were isolated and purified from nodules by using a sequential sucrose gradient method as previously described (Green and Emerich 1997). The gradient consisted of 42 and 57\% (wt/wt) sucrose in MEP buffer $(5 \mathrm{mM}$ $\mathrm{MgCl}_{2}, 1 \mathrm{mM}$ EDTA, and $50 \mathrm{mM}$ potassium phosphate buffer, $\mathrm{pH}$ 7.0). RNA was isolated as described for free-living $B . j a$ ponicum.

\section{RNA isolation.}

A $250-\mathrm{ml}$ culture of $B$. japonicum USDA110 was grown to mid-log phase, optical density at $600 \mathrm{~nm}=0.4$ to 0.6 , and immediately transferred to centrifuge tubes containing $25 \mathrm{ml}$ of cold stop solution The suspension was centrifuged for $10 \mathrm{~min}$ at $4^{\circ} \mathrm{C}$ at $9,700 \times g$, and cell pellets were frozen immediately in liquid nitrogen and stored at $-80^{\circ} \mathrm{C}$ until RNA isolation. RNA was isolated using a hot phenol method as described previously (Bittner et al. 2003). The RNA samples were treated with DNase I (10 units, Promega Corp., Madison, WI, U.S.A.) and RNase inhibitor (40 units, Promega Corp.) for $30 \mathrm{~min}$ at $37^{\circ} \mathrm{C}$, followed by phenol-chloroform extraction and column purification using the RNeasy Mini Kit (Qiagen, Germantown, MD, U.S.A.). The integrity of all RNA samples was confirmed on $0.8 \%$ agarose gels.

\section{cDNA synthesis and hybridization.}

Experiments to test microarray performance were done at the Genome Sequencing Center at Washington University. Initial studies compared transcription profiles of B. japonicum cells grown in minimal and rich medium. cDNA synthesis, hybridization, and scanning were performed as described on the center website (Author-Recommended Internet Resources). Raw data were obtained and analyzed as indicated below. Subsequent experiments were done to compare transcriptomes of cells grown with and without osmotic stress, or free-living cells versus bacteroids. These studies were done at the University of Minnesota and the University of Missouri, respectively. cDNA was synthesized and labeled as described previously (Bittner et al. 2003). Briefly, $20 \mu \mathrm{g}$ of total RNA was used for cDNA synthesis with superscript III reverse transcriptase and random hexamers (Invitrogen Corp., Carlsbad, CA, U.S.A.). After digesting the remaining RNA by RNase H (Fermentas, Glen Burnie, MD, U.S.A.), cDNA was purified using a Microcon YM-30 column (Millipore, Bedford, MA, U.S.A.) and concentration was determined using a Nanodrop spectrophotometer (NanoDrop Technologies, Wilmington, DE, U.S.A.). cDNA (4 $\mu \mathrm{g})$ was used for labeling with either cy3 or cy5 (Amersham, Buckinghamshire, U.K.) and unincorporated dyes were removed using a Qiaquick PCR purification Kit (Qiagen).

Both cy3- and cy5-labeled cDNAs to be compared were mixed, dried to completion, and then resuspended in $70 \mu \mathrm{l}$ of preheated hybridization buffer (nuclease-free water/formamide/ $20 \times \mathrm{SSC}$ [ $1 \times \mathrm{SSC}$ is $0.15 \mathrm{M} \mathrm{NaCl}$ plus $0.015 \mathrm{M}$ sodium citrate]/ $1 \%$ sodium dodecyl sulfate $[\mathrm{SDS}]=4: 2.5: 2.5: 1)$ at $42^{\circ} \mathrm{C}$. After adding $0.7 \mu \mathrm{l}$ of salmon sperm DNA $(10 \mathrm{mg} / \mathrm{ml})$ to prevent nonspecific binding to the array, the mixture was hybridized at $42^{\circ} \mathrm{C}$ for 16 to $18 \mathrm{~h}$. Hybridized arrays were washed with $1 \times$ SSC and $0.2 \% \mathrm{SDS}$ at $42^{\circ} \mathrm{C}$ for $6 \mathrm{~min}$ and, subsequently, with 
$0.1 \times \mathrm{SSC}$ and $0.2 \% \mathrm{SDS}$ at room temperature for $6 \mathrm{~min}$, and twice with $0.1 \times \mathrm{SSC}$ at room temperature for $3 \mathrm{~min}$. The arrays were scanned using an Axon GenePix 4000B scanner (Molecular Devices Corp., Sunnyvale, CA, U.S.A.).

\section{Data analysis.}

Signal intensities from six slides were analyzed using GenePix Pro 6.0 software (Molecular Devices Corp.) for minimal versus rich medium and free-living cells versus bacteroid comparisons, whereas those from four slides were analyzed for osmotic stress responses. Signal intensities were normalized for spot and slide abnormalities using spatial lowess, and then lowess-adjusted data subsequently were analyzed by mixed effect microarray analysis of variance (MAANOVA) (Kerr et al. 2000). The resulting variety-gene interaction values were combined with the residual noise from each spot to obtain the filtered and adjusted expression values (Kerr and Churchill 2001; Kerr et al. 2000). Both lowess and MAANOVA are part of the $\mathrm{R} / \mathrm{maanova}$ microarray statistical analysis package (Author-Recommended Internet Resources). Expression values from two technical replicates in each array were combined, averaged, and subsequently subjected to significance analysis of microarray (SAM) using the SAM package (Tusher et al. 2001). Significant genes were selected based on a 1.5- or 2-fold cut off threshold with a false discovery rate lower than $5 \%$.

\section{qRT-PCR analysis.}

To validate the microarray data, the expression of several genes was measured by qRT-PCR using the same RNA samples as used in the microarray experiments. Total RNA was reverse transcribed to generate $\mathrm{cDNA}$, followed by quantitative PCR amplification using SYBR Green Master Mix (Applied Biosystems, Foster City, CA, U.S.A.) and gene-specific primers (Table 1) whose amplicon sizes were 80 to $120 \mathrm{bp}$. Genomic DNA contamination was checked with a control reaction mixture not containing reverse transcriptase. PCR reactions were monitored using an ABI 7500 Real Time PCR System with Sequence Detection System software (version 1.3; Applied Biosystems). PCR conditions were: stage $1,50^{\circ} \mathrm{C}$ for $2 \mathrm{~min}$; stage $2,95^{\circ} \mathrm{C}$ for $10 \mathrm{~min}$; stage 3,45 cycles of $95^{\circ} \mathrm{C}$ for $15 \mathrm{~s}$ and $60^{\circ} \mathrm{C}$ for $1 \mathrm{~min}$; stage 4 (for dissociation), $95^{\circ} \mathrm{C}$ for $15 \mathrm{~s}$, $60^{\circ} \mathrm{C}$ for $1 \mathrm{~min}$, and $95^{\circ} \mathrm{C}$ for $15 \mathrm{~s}$. All expression values from two to three technical replicates of each biological replicate were normalized to the expression of bll7457 (hisS) encoding histidly t-RNA synthetase, a gene constitutively expressed under all conditions used.

\section{Microarray data availability.}

All of the microarray data have been deposited in Gene Expression Omnibus (GEO) (Author-Recommended Internet Resources) and are accessible through GEO series accession numbers GSE8033, GSE8036, and GSE8042 for rich versus minimal medium, osmotic stress, and free-living cells versus bacteroids, respectively.

\section{ACKNOWLEDGMENTS}

This research was supported by grant 2004-35604-14708 from USDA/CSREES/NRI. We thank B. Valliyodan for helping us with cDNA synthesis, hybridization, and scanning, and S. Crosby and M. Heinz at the Genome Sequencing Center at Washington University School of Medicine for slide printing and conducting the initial microarray hybridizations. We also thank D. Sangurdekar for help with statistics.

\section{LITERATURE CITED}

Ampe, F., Kiss, E., Sabourdy, F., and Batut, J. 2003. Transcriptome analysis of Sinorhizobium meliloti during symbiosis. Genome Biol. 4:R15.
Appleby, C. A., Turner, G. L., and Macnicol, P. K. 1975. Involvement of oxyleghaemoglobin and cytochrome P-450 in an efficient oxidative phosphorylation pathway which supports nitrogen fixation in Rhizobium. Biochim. Biophys. Acta 387:461-474.

Aspedon, A., Palmer, K., and Whiteley, M. 2006. Microarray analysis of the osmotic stress response in Pseudomonas aeruginosa. J. Bacteriol. 188:2721-2725.

Barloy-Hubler, F., Cheron, A., Hellegouarch, A., and Galibert, F. 2004 Smc01944, a secreted peroxidase induced by oxidative stresses in $\mathrm{Si}$ norhizobium meliloti 1021. Microbiology 150:657-664.

Barnett, M. J., and Fisher, R. F. 2006. Global gene expression in the rhizobial-legume symbiosis. Symbiosis 42:1-24.

Barnett, M. J., Toman, C. J., Fisher, R. F., and Long, S. R. 2004. A dualgenome symbiosis chip for coordinate study of signal exchange and development in a prokaryote-host interaction. Proc. Natl. Acad. Sci. U.S.A. 101:16636-16641.

Becker, A., Berges, H., Krol, E., Bruand, C., Ruberg, S., Capela, D., Lauber, E., Meilhoc, E., Ampe, F., de Bruijn, F. J., Fourment, J., Francez-Charlot, A., Kahn, D., Kuster, H., Liebe, C., Puhler, A., Weidner, S., and Batut, J. 2004. Global changes in gene expression in Sinorhizobium meliloti 1021 under microoxic and symbiotic conditions. Mol. Plant-Microbe Interact. 17:292-303.

Bellato, C., Krishnan, H. B., Cubo, T., Temprano, F., and Pueppke, S. G. 1997. The soybean cultivar specificity gene nolX is present, expressed in a nodD-dependent manner, and of symbiotic significance in cultivarnonspecific strains of Rhizobium (Sinorhizobium) fredii. Microbiology 143:1381-1388.

Berges, H., Lauber, E., Liebe, C., Batut, J., Kahn, D., de Bruijn, F. J., and Ampe, F. 2003. Development of Sinorhizobium meliloti pilot macroarrays for transcriptome analysis. Appl. Environ. Microbiol. 69:1214-1219.

Bishop, P. E., Guevara, J. G., Engelke, J. A., and Evans, H. J. 1976. Relation between glutamine synthetase and nitrogenase activities in the symbiotic association between Rhizobium japonicum and Glycine max. Plant Physiol. 57:542-546.

Bittner, M., Butow, R., DeRisi, J., Diehn, M., Eberwine, J., Epstein, C. B. Glynne, R., Grimmond, S., Ideker, T., Kacharmina, J. E., Katsabanis, S., Khan, J., Lee, J., Liu, C. L., Marciano, P., Marincola, F. M., McIntosh, T., Monte, D., Pollack, J. R., Rhodius, V., Somerville, S., Tom, E., Wang, E., Wei, J. S., Willhite, D., and Ybarra, S. 2003. Expression analysis of RNA. Pages 101-288 in: DNA Microarrays: A Molecular Cloning Manual. D. Bowtell, and J. Sambrook, eds. Cold Spring Harbor Laboratory Press, Cold Spring Harbor, NY, U.S.A.

Boncompagni, E., Osteras, M., Poggi, M. C., and le Rudulier, D. 1999. Occurrence of choline and glycine betaine uptake and metabolism in the family Rhizobiaceae and their roles in osmoprotection. Appl. Environ. Microbiol. 65:2072-2077.

Boscari, A., Mandon, K., Poggi, M. C., and Le Rudulier, D. 2004. Functional expression of Sinorhizobium meliloti BetS, a high-affinity betaine transporter, in Bradyrhizobium japonicum USDA110. Appl. Environ. Microbiol. 70:5916-5922.

Budde, I., Steil, L., Scharf, C., Volker, U., and Bremer, E. 2006. Adaptation of Bacillus subtilis to growth at low temperature: A combined transcriptomic and proteomic appraisal. Microbiology 152:831-853.

Campbell, G. R., Taga, M. E., Mistry, K., Lloret, J., Anderson, P. J., Roth, J. R., and Walker, G. C. 2006. Sinorhizobium meliloti bluB is necessary for production of 5,6-dimethylbenzimidazole, the lower ligand of $\mathrm{B}_{12}$. Proc. Natl. Acad. Sci. U.S.A. 103:4634-4639.

Csonka, L. N. 1989. Physiological and genetic responses of bacteria to osmotic stress. Microbiol. Rev. 53:121-147.

Daniel, R. M., and Appleby, C. A. 1972. Anaerobic-nitrate, symbiotic and aerobic growth of Rhizobium japonicum: Effects on cytochrome P 450, other haemoproteins, nitrate and nitrite reductases. Biochim. Biophys. Acta 275:347-354.

Davalos, M., Fourment, J., Lucas, A., Berges, H., and Kahn, D. 2004. Nitrogen regulation in Sinorhizobium meliloti probed with whole genome arrays. FEMS (Fed. Eur. Microbiol. Soc.) Microbiol. Lett. 241:33-40.

Dominguez-Ferreras, A., Perez-Arnedo, R., Becker, A., Olivares, J., Soto, M. J., and Sanjuan, J. 2006. Transcriptome profiling reveals the importance of plasmid pSymB for osmoadaptation of Sinorhizobium meliloti. J. Bacteriol. 188:7617-7625.

Elsheikh, E. A. E. 1998. Effects of salt on rhizobia and bradyrhizobia: A review. Ann. Appl. Biol. 132:507-524.

Elsheikh, E. A. E., and Wood, M. 1990. Rhizobia and bradyrhizobia under salt stress: Possible role of trehalose in osmoregulation. Lett. Appl. Microbiol. 10:127-129.

Fischer, H. M. 1994. Genetic regulation of nitrogen fixation in rhizobia. Microbiol. Rev. 58:352-386.

Galibert, F., Finan, T. M., Long, S. R., Puhler, A., Abola, P., Ampe, F. Barloy-Hubler, F., Barnett, M. J., Becker, A., Boistard, P., Bothe, G., Boutry, M., Bowser, L., Buhrmester, J., Cadieu, E., Capela, D., Chain, 
P., Cowie, A., Davis, R. W., Dreano, S., Federspiel, N. A., Fisher, R. F., Gloux, S., Godrie, T., Goffeau, A., Golding, B., Gouzy, J., Gurjal, M., Hernandez-Lucas, I., Hong, A., Huizar, L., Hyman, R. W., Jones, T., Kahn, D., Kahn, M. L., Kalman, S., Keating, D. H., Kiss, E., Komp, C., Lelaure, V., Masuy, D., Palm, C., Peck, M. C., Pohl, T. M., Portetelle, D., Purnelle, B., Ramsperger, U., Surzycki, R., Thebault, P., Vandenbol, M., Vorholter, F. J., Weidner, S., Wells, D. H., Wong, K., Yeh, K. C., and Batut, J. 2001. The composite genome of the legume symbiont Sinorhizobium meliloti. Science 293:668-672.

Gonzalez, V., Santamaria, R. I., Bustos, P., Hernandez-Gonzalez, I., Medrano-Soto, A., Moreno-Hagelsieb, G., Janga, S. C., Ramirez, M. A., Jimenez-Jacinto, V., Collado-Vides, J., and Davila, G. 2006. The partitioned Rhizobium etli genome: Genetic and metabolic redundancy in seven interacting replicons. Proc. Natl. Acad. Sci. U.S.A. 103:3834-3839.

Green, L. S., and Emerich, D. W. 1997. The formation of nitrogen-fixing bacteroids is delayed but not abolished in soybean infected by an $\alpha$-ketoglutarate dehydrogenase-deficient mutant of Bradyrhizobium japonicum. Plant Physiol. 114:1359-1368.

Hauser, F., Lindemann, A., Vuilleumier, S., Patrignani, A., Schlapbach, R., Fischer, H. M., and Hennecke, H. 2006. Design and validation of a partial-genome microarray for transcriptional profiling of the Bradyrhizobium japonicum symbiotic gene region. Mol. Genet. Genomics 275:55-67.

Kaneko, T., Nakamura, Y., Sato, S., Asamizu, E., Kato, T., Sasamoto, S., Watanabe, A., Idesawa, K., Ishikawa, A., Kawashima, K., Kimura, T., Kishida, Y., Kiyokawa, C., Kohara, M., Matsumoto, M., Matsuno, A., Mochizuki, Y., Nakayama, S., Nakazaki, N., Shimpo, S., Sugimoto, M., Takeuchi, C., Yamada, M., and Tabata, S. 2000. Complete genome structure of the nitrogen-fixing symbiotic bacterium Mesorhizobium loti. DNA Res. 7:331-338.

Kaneko, T., Nakamura, Y., Sato, S., Minamisawa, K., Uchiumi, T., Sasamoto, S., Watanabe, A., Idesawa, K., Iriguchi, M., Kawashima, K., Kohara, M., Matsumoto, M., Shimpo, S., Tsuruoka, H., Wada, T., Yamada, M., and Tabata, S. 2002. Complete genomic sequence of nitrogen-fixing symbiotic bacterium Bradyrhizobium japonicum USDA110. DNA Res. 9:189-197.

Karr, D. B., Waters, J. K., Suzuki, F., and Emerich, D. W. 1984. Enzymes of the poly-beta-hydroxybutyrate and citric acid cycles of Rhizobium japonicum bacteroids. Plant Physiol. 75:1158-1162.

Keister, D. L., Tully, R. E., and Van Berkum, P. 1999. A cytochrome P450 gene cluster in the Rhizobiaceae. J. Gen. Appl. Microbiol. 45:301-303.

Kerr, M. K., and Churchill, G. A. 2001. Statistical design and the analysis of gene expression microarray data. Genet. Res. 77:123-128.

Kerr, M. K., Martin, M., and Churchill, G. A. 2000. Analysis of variance for gene expression microarray data. J. Comput. Biol. 7:819-837.

Krause, A., Doerfel, A., and Gottfert, M. 2002. Mutational and transcriptional analysis of the type III secretion system of Bradyrhizobium japonicum. Mol. Plant-Microbe Interact. 15:1228-1235.

Larsen, S. H., Adler, J., Gargus, J. J., and Hogg, R. W. 1974. Chemomechanical coupling without ATP: The source of energy for motility and chemotaxis in bacteria. Proc. Natl. Acad. Sci. U.S.A. 71:1239-1243.

Layzell, D. B., Hunt, S., and Palmer, G. R. 1990. Mechanism of nitrogenase inhibition in soybean nodules: Pulse-modulated spectroscopy indicates that nitrogenase activity is limited by $\mathrm{O}_{2}$. Plant Physiol. 92:1101-1107.

Li, C., Louise, C. J., Shi, W., and Adler, J. 1993. Adverse conditions which cause lack of flagella in Escherichia coli. J. Bacteriol. 175:2229-2235.

Liu, Y., Gao, W., Wang, Y., Wu, L., Liu, X., Yan, T., Alm, E., Arkin, A., Thompson, D. K., Fields, M. W., and Zhou, J. 2005. Transcriptome analysis of Shewanella oneidensis MR-1 in response to elevated salt conditions. J. Bacteriol. 187:2501-2507.

Manson, M. D., Tedesco, P., Berg, H. C., Harold, F. M., and Van der Drift, C. 1977. A protonmotive force drives bacterial flagella. Proc. Natl. Acad. Sci. U.S.A. 74:3060-3064.

Meinhardt, L. W., Krishnan, H. B., Balatti, P. A., and Pueppke, S. G. 1993. Molecular cloning and characterization of a sym plasmid locus that regulates cultivar-specific nodulation of soybean by Rhizobium fredii USDA257. Mol. Microbiol. 9:17-29.

Mergaert, P., Uchiumi, T., Alunni, B., Evanno, G., Cheron, A., Catrice, O., Mausset, A. E., Barloy-Hubler, F., Galibert, F., Kondorosi, A., and Kondorosi, E. 2006. Eukaryotic control on bacterial cell cycle and differentiation in the Rhizobium-legume symbiosis. Proc. Natl. Acad. Sci. U.S.A. 103:5230-5235.

Puskas, L. G., Nagy, Z. B., Kelemen, J. Z., Ruberg, S., Bodogai, M., Becker, A., and Dusha, I. 2004. Wide-range transcriptional modulating effect of $n t r R$ under microaerobiosis in Sinorhizobium meliloti. Mol. Genet. Genomics 272:275-289.

Roughley, R. J., Gemell, L. G., Thompson, J. A., and Brockwell, J. 1993. The number of Bradyrhizobium sp. (Lupinus) applied to seed and its effect on rhizosphere colonization, nodulation and yield of lupin. Soil Biol. Biochem. 25:1453-1458.

Ruberg, S., Tian, Z. X., Krol, E., Linke, B., Meyer, F., Wang, Y., Puhler, A., Weidner, S., and Becker, A. 2003. Construction and validation of a Sinorhizobium meliloti whole genome DNA microarray: Genome-wide profiling of osmoadaptive gene expression. J. Biotechnol. 106:255-268.

Rudolph, G., Semini, G., Hauser, F., Lindemann, A., Friberg, M., Hennecke, H., and Fischer, H. M. 2006. The iron control element, acting in positive and negative control of iron-regulated Bradyrhizobium japonicum genes, is a target for the Irr protein. J. Bacteriol. 188:733-744.

Schwinghamer, E. A. 1970. Requirement of riboflavin for effective symbiosis of clover by an auxotrophic mutant strain of Rhizobium trifolii. Aust. J. Biol. Sci. 26:1118-1196.

Steil, L., Hoffmann, T., Budde, I., Volker, U., and Bremer, E. 2003. Genome-wide transcriptional profiling analysis of adaptation of Bacillus subtilis to high salinity. J. Bacteriol. 185:6358-6370.

Streit, W. R., Joseph, C. M., and Phillips, D. A. 1996. Biotin and other water-soluble vitamins are key growth factors for alfalfa root colonization by Rhizobium meliloti 1021. Mol. Plant-Microbe Interact. 9:330338.

Suss, C., Hempel, J., Zehner, S., Krause, A., Patschkowski, T., and Gottfert, M. 2006. Identification of genistein-inducible and type III-secreted proteins of Bradyrhizobium japonicum. J. Biotechnol. 126:69-77.

Tao, H., Bausch, C., Richmond, C., Blattner, F. R., and Conway, T. 1999. Functional genomics: Expression analysis of Escherichia coli growing on minimal and rich media. J. Bacteriol. 181:6425-6440.

Tully, R. E., and Keister, D. L. 1993. Cloning and mutagenesis of a cytochrome P-450 locus from Bradyrhizobium japonicum that Is expressed anaerobically and symbiotically. Appl. Environ. Microbiol. 59:4136-4142.

Tusher, V. G., Tibshirani, R., and Chu, G. 2001. Significance analysis of microarrays applied to the ionizing radiation response. Proc. Natl. Acad. Sci. U.S.A. 98:5116-5121.

Uchiumi, T., Ohwada, T., Itakura, M., Mitsui, H., Nukui, N., Dawadi, P., Kaneko, T., Tabata, S., Yokoyama, T., Tejima, K., Saeki, K., Omori, H., Hayashi, M., Maekawa, T., Sriprang, R., Murooka, Y., Tajima, S., Simomura, K., Nomura, M., Suzuki, A., Shimoda, Y., Sioya, K., Abe, M., and Minamisawa, K. 2004. Expression islands clustered on the symbiosis island of the Mesorhizobium loti genome. J. Bacteriol. 186:2439-2448.

Viprey, V., Del Greco, A., Golinowski, W., Broughton, W. J., and Perret, X. 1998. Symbiotic implications of type III protein secretion machinery in Rhizobium. Mol. Microbiol. 28:1381-1389.

White, D. 2000a. Structure and function. Pages 1-36 in: The Physiology and Biochemistry of Prokaryotes. Oxford University Press, Inc., New York.

White, D. 2000b. Inorganic Metabolism. Pages 314-337 in: The Physiology and Biochemistry of Prokaryotes. Oxford University Press, Inc., New York.

Wood, J. M. 1999. Osmosensing by bacteria: Signals and membrane-based sensors. Microbiol. Mol. Biol. Rev. 63:230-262.

Yang, J., Sangwan, I., Lindemann, A., Hauser, F., Hennecke, H., Fischer, H. M., and O'Brian, M. R. 2006. Bradyrhizobium japonicum senses iron through the status of haem to regulate iron homeostasis and metabolism. Mol. Microbiol. 60:427-437.

Young, J. P., Crossman, L. C., Johnston, A. W., Thomson, N. R., Ghazoui, Z. F., Hull, K. H., Wexler, M., Curson, A. R., Todd, J. D., Poole, P. S., Mauchline, T. H., East, A. K., Quail, M. A., Churcher, C., Arrowsmith, C., Cherevach, I., Chillingworth, T., Clarke, K., Cronin, A., Davis, P., Fraser, A., Hance, Z., Hauser, H., Jagels, K., Moule, S., Mungall, K., Norbertczak, H., Rabbinowitsch, E., Sanders, M., Simmonds, M., Whitehead, S., and Parkhill, J. 2006. The genome of Rhizobium leguminosarum has recognizable core and accessory components. Genome Biol. 7:R34.

Zahran, H. H. 1999. Rhizobium-legume symbiosis and nitrogen fixation under severe conditions and in an arid climate. Microbiol. Mol. Biol. Rev. 63:968-989.

\section{AUTHOR RECOMMENDED INTERNET RESOURCES}

Bradyrhizobium Microarray Initiative website: www.bradygenome.org Gene Expression Omnibus (GEO) website: www.ncbi.nlm.nih.gov/geo/ GeneMark website: exon.gatech.edu/GeneMark

The Genome Sequencing Center at Washington University: genome.wustl.edu/services/microarray.cgi

Glimmer2 website: www.cbcb.umd.edu/software/glimmer

The Jackson Laboratory statistical analysis website: www.jax.org/staff/churchill/labsite/

Kazusa DNA Research Institute RhizoBase webase: www.kazusa.or.jp/rhizobase 